\title{
Foreign Language Learners' Motivation and Its Effects on Their Achievement: Implications for Effective Teaching of Students Studying Japanese at Universiti Brunei Darussalam
}

\author{
Minako Keaney ${ }^{1}$ \& Lawrence Mundia ${ }^{2}$ \\ ${ }^{1}$ Language Centre, Universiti Brunei Darussalam, Bandar Seri Begawan, Brunei Darussalam \\ ${ }^{2}$ Sultan Hassanal Bolkiah Institute of Education, Universiti Brunei Darussalam, Bandar Seri Begawan, Brunei \\ Darussalam \\ Correspondence: Lawrence Mundia, Sultan Hassanal Bolkiah Institute of Education, Universiti Brunei \\ Darussalam, Jalan Tungku Link, Gadong, BE 1410, Bandar Seri Begawan, Brunei Darussalam. Tel: \\ 673-246-3001. E-mail: lawrence.mundia@ubd.edu.bn
}

Received: June 11, 2014 Accepted: July 16, 2014 Online Published: August 17, 2014

doi:10.5539/ies.v7n9p122 URL: http://dx.doi.org/10.5539/ies.v7n9p122

\begin{abstract}
An increasing number of students at the University of Brunei Darussalam are studying the Japanese language. However, research on the relationship between learners' motivation and their achievement has not been given sufficient attention in Japanese foreign language education compared to English in Brunei. The present study, which utilized a quantitative survey, attempted to address this information gap. Based on the Brunei university student sample, five main motivational factors were extracted by factor analysis, namely: (1) Interest in Japanese pop culture and traditional culture; (2) Interest in Japanese language orientation; (3) Understanding Japanese people and society orientation; (4) Career use of Japanese language orientation; and (5) Self-satisfaction orientation. Participants differed significantly in their Japanese language learning motivation by gender and age. Male students were more driven to study Japanese language by Factor 1-Interest in Japanese pop culture and traditional culture orientation while females were inspired mostly by Factor 5-Self-satisfaction Orientation. In addition, students placed in the oldest age-group category (24-27) scored significantly higher on Factor 3-Understanding Japanese people and society orientation, than members of the other two age-groups. Based on these findings, nine recommendations were made to improve the teaching and learning of Japanese language at the university. Further mixed-methods research was also recommended to gain additional insights.
\end{abstract}

Keywords: Japanese language, factor analysis, motivation, foreign students, teaching, learning, achievement

\section{Introduction}

Human behaviour is always generated by either an inner force commonly known as internal motivation or an outside force referred to as external motivation. Nobody knows exactly what "motivation" is since it is a psychological construct that cannot be seen, touched and felt. Despite this, the concept of motivation is observable thorough peoples' behaviour in everyday life and psychologists have developed various procedures for assessing it. However, assessing motivation through observation is a tricky business that entails waiting long periods of time for natural instances of motivated behaviour to occur. This is due to human beings' tendency to conceal some types of motivations particularly negative ones. Thus the term motivation has been defined in many ways (Silva \& Weinberg, 1984). One of the definitions describes motivation as an internal state that drives an organism to act in one way or another (Flanagan, 2000). According to Silva and Weinberg (1984), internal motivation has two distinct aspects: direction and intensity. These authors argue that the direction component of motivated behaviour indicates whether an individual approaches or avoids a particular situation while the intensity part refers to the degree of effort put forth to accomplish the behaviour. In this way, motivation can affect the selection, strength, and persistence of an individual's behaviour.

\subsection{Classical Theories of Internal Motivation}

A number of human behaviours have always attracted the attention of researchers. At a homicide crime scene, for example, people often try to determine: "what was the motive behind the murder? Several other questions can be asked. During war, for instance, what motivates soldiers in a risky and vulnerable environment to fight on? In 
sports, we usually wonder what urges players to persist in the game even when they are fully aware of being in the losing team. Similarly in education we may ask, "what motivates students to learn difficult subjects such as mathematics, engineering, and languages like Arabic, Chinese or Japanese that use complex symbols to read and write?". Research on motivation has led to the emergence of a number of theories that attempt to explain why people behave or avoid behaving in certain ways. Theories of motivation come under three broad categories: (1) physiological approaches e.g. Maslow's hierarchical needs; (2) psychological approaches e.g. the need for achievement; and (3) combined approaches-physiological and psychological e.g. Freud's psychoanalysis. A full description of all these types of theories is, however, outside the objectives and beyond the scope of the present study.

\subsection{Brunei Studies with a Bearing on Students' Motivation}

Prior to 1996, the Brunei education system was examination-oriented (Mundia, 2010a). The exams enabled the students to develop internal motivation (e.g. possessing good ability in mathematics) but also to look for sources of external motivation such as teachers and peers. Adaptations to examinations and a reduction of dependence on examinations as a dominant mode for evaluating students were introduced with the implementation of inclusive education in 1997 (Mundia, 2009). Further adaptations to examinations and reduction of dependence on examination-type assessments continued to be made after the implementation of both the ongoing SPN21 educational reforms and inclusive education (Mundia, 2009, 2010a). Mathematics is one of the subjects that challenge Brunei secondary school students along with Science and English (Ang \& Shahrill, 2014; Go \& Shahrill, 2014; Mahadi \& Shahrill, 2014; Nor \& Shahrill, 2014; Pungut \& Shahrill, 2014; Salam \& Shahrill, 2014; Sarwadi \& Shahrill, 2014; Wahid \& Shahrill, 2014; Yatab \& Shahrill, 2014a, 2014b; Shahrill, 2009). These three constitute key subjects used in the selection criteria of students for admission into Brunei tertiary institutions as well as for award of scholarships. Unfortunately, performance in mathematics is often poor particularly among male students. Coupled with this, in an educational system in which student evaluations were frequent, it is quite possible that the assessments may produce a lot of tension, anxiety and stress in students.

Recent past research efforts to know more about secondary students' motivations in confronting mathematics problems have focused on a wide-range of issues other than test anxiety (that touch on mathematics in one way or the other) including the preparation of teachers to meet the challenges of inclusive education (Tait \& Mundia, 2012a); comparison of Brunei pre-service student teachers' attitudes to inclusive education and specific disabilities (Haq \& Mundia, 2012); policy changes in Brunei teacher education (Mundia, 2012a); assessment of mathematics learning difficulties (Mundia, 2012b); overall improvement of university education including teacher programs (Mundia, 2012c); problems in learning mathematics (Mundia, 2010b); implementation of SPN21 curriculum (Mundia, 2010a); and implementation of inclusive education (Bradshaw \& Mundia, 2006; Mundia, 2009). The way an instructor uses questions during expository teaching could also be a source of motivation in learning (Salam \& Shahrill, 2014; Shahrill \& Clarke, 2014; Shahrill \& Mundia, 2014b; Shahrill, 2009, 2013a, 2013b). These studies have addressed a wide range of issues and problems related to teaching and learning in Brunei educational institutions including the motivation of students. For example, Bradshaw and Mundia (2006) and Mundia (2009, 2010b) found that under inclusive education, teachers in Brunei needed to develop affective-oriented skills to provide pastoral care to disabled students integrated in ordinary classrooms. Also, Mundia (2010b) suggested that instructors should use teaching methods that can help all categories of students (especially the less able and disabled) to create and maintain high level of interest and motivation in learning.

The preparation of teachers and parents who can effectively motivate learners had been adequately discussed in the following studies, for example by Tait and Mundia (2012a, 2012b), Haq and Mundia (2012), Mundia, (2012a) and Mundia (2012c). Teachers in Brunei need to help students who are struggling in mathematics to develop appropriate internal and external motivations towards the subject and this can be done in many ways as recommended in Mundia (2010b, 2010c, 2012b). In addition, evidence from previous research has indicated that school subjects that are relevant to careers are also sources of both internal and external motivation in learning to students particularly school leavers and school dropouts (Mundia, 1998).

A more recent study by Matzin et al. (2013) assessed the learning styles and study strategies of 135 randomly selected Brunei secondary school students according to their test anxiety levels, internal-external attributions for success, and internal-external attributions for failing. Four significant differences were obtained on learning styles but only one was found on study strategies. Highly anxious students scored higher on the social-individual learning style than their less anxious peers implying that they were low on internal or self-motivation. However, learners who internalize success attributions scored higher on the social-group learning style suggesting that they benefitted from external motivation. Participants with internal attributions for failing, scored higher on both the 
visual-language and expressive-written learning styles than those who externalize reasons for failing. Paradoxically, females were the most affected by test anxiety and yet they outperformed males in mathematics achievement. Matzin et al. (2013) discussed the plausible explanations for these findings and suggested psychological and educational interventions to address the observed deficiencies, which included internal motivation.

There are many other motivational challenges learners in Brunei educational institutions face. For example, repeated failure or lack of experience of success appears to act as negative external motivation (see Hamid et al., 2013; Sarwadi \& Shahrill, 2014). In addition, students' inability to effectively cope with their personal and academic problems is another seemingly demotivating factor (Mundia, 2010c; Shahrill \& Mundia, 2014a; Wahid \& Shahrill, 2014). Furthermore, there was evidence that the learning styles and study strategies used by students contributed to developing internal and external motivation for effective learning as recently found by Shahrill, Mahalle et al. (2013). These authors identified some of the learning styles and strategies adopted by high performing students. Moreover, self-efficacy also positively affects the students' internal motivation in learning (Tait \& Mundia, 2014). This is more so when it comes to answering higher order questions both verbally and in writing (Shahrill \& Mundia, 2014b). The problem in assessing motivation among Brunei learners may partly be attributed to lack of suitable instruments to measure the attribute. Most of the available western instruments are written in English language and have to be modified or translated into Bahasa Melayu, the mother tongue and official language of Brunei, to be reliable and valid for use in Brunei (see Mundia \& Bakar, 2010; Mundia, 2011).

There are two other ways students can be helped to develop positive motivation. First, teachers who lack the ability to foster students' motivation could work collaboratively with colleagues who know how to do this through team teaching. However, such cooperative work requires teachers to have good interpersonal trust with each other. Recent research has shown that Brunei teachers may be able to work together in a group setting (Daud \& Shahrill, 2014; Jawawi, 2009, 2010; Mahalle et al., 2014; Nor \& Shahrill, 2014; Wahid \& Shahrill, 2014; Shahrill, 2009). Second, parents could be used as facilitators in helping learners to develop and maintain external motivation to learn (Jaidin, 2009; Shahrill, Abdullah, \& Yusof, 2014; Shahrill, Abdullah et al., 2014; Shahrill, Lim et al., 2013), and this is particularly necessary when the student has special needs (Tait \& Mundia, 2012; Tait et al., 2014).

\subsection{Motivation in Studying Japanese Language}

A number of studies that investigated the motive for studying the Japanese language in countries other than Japan have been conducted (for example, Guo \& Okita, 2001; Guo \& Quan, 2006; Nuibe, Kano, \& Ito, 1995; Onishi, 2011; Seo, 2011). Motivation has long been considered a seminal issue in language education research (see Dörnyei, 2001). According to Dörnyei (2001), learning the Japanese language by non-native speakers can be enjoyable and successful provided that the teachers' instruction and class activities meet the learners' needs and goals. In addition, motivation has also been considered as one of the most important factors for success in second language and foreign language acquisition (Gardner, 1985; Gardner et al., 1987). In addition, the instructor has to help the learners in developing confidence, self-efficacy, and motivation. From such a focus on the importance of motivation in language learning, a number of models of second language acquisition such as Krashen's (1981) Monitor Model and Schuman's (1986) Acculturation Model were created. Krashen's model explains that language acquisition is a subconscious process in which new languages are received and interpreted through the context surrounding them while language learning is a conscious process where new language is gained by studying or practising.

However, the most influential model of second language acquisition is the Socio Educational Model, which was developed in the mid-1970s by Gardner (see Gardner, 1985). Motivation is seen as a crucial element for maintaining language proficiency even though learning activities finish at schools (Gardner et al., 1987). Gardner and Lambert (1972) identified two types of motivation: Integrative Motivation and Instrumental Motivation. Integrative Motivation referred to motivation caused by a personal and strong interest in the culture and customs of the foreign language and an integrative orientation in the foreign language group, while instrumental motivation referred to practically-oriented motivation such as passing exams or pursuing one's career prospects. Gardner and Lambert (1972) hypothesized that the second language learners who have integrative motivation would achieve their goals more successfully than those who have instrumental motivation. Thus, the discussion on integrative motivation and instrumental motivation developed into how either motivation was related to high achievement, rather than determining which type of motivation was superior (Moriya 2002). This is because the effects of integrative and instrumental motivation on learners differ according to the environments or situations where the learners reside (Moriya, 2002). 


\subsection{Purpose of the Study}

The main goal of the present research was to investigate the motivation of students studying the Japanese language in the Language Centre at the University of Brunei Darussalam. Our main objectives were to:

- Determine the types of motivation students employ in studying Japanese language.

- Measure differences in students' motivation by gender.

- Identify students' motivation by age-groups.

- Assess differences in students' motivation by proficiency level in Japanese language.

- Find out differences in students' motivation by overall achievement grades obtained in Japanese language courses.

\section{Methods}

The research strategies adopted by the present study are described below under separate subheadings.

\subsection{Design}

We investigated the topic using the quantitative field survey approach. This procedure required the researchers to go to relevant fields (environments or contexts which were Japanese language classrooms in the present study) and collect data directly from the participants. The method was thus different from other forms of survey research such as the longitudinal, postal, online, and telephone surveys. However, the present study was also partly cross-sectional in the sense that data came from different categories of students as explained further in the data analysis section below. The rationale and justification for making the design cross-sectional was to determine whether there were any significant changes in participants' motivation for studying the Japanese language with an increase in age.

\subsection{Participants}

The study involved all students on the university of Brunei Darussalam's (hereafter, referred to as UBD) main campus who were studying Japanese language during the semester and academic year when data were collected. These included 30 students in the pilot phase and 141 students in the main study taking Japanese language (Levels 1, 2, 3, 4, and 6). All Level 5 students were excluded from the study as they were either on the discovery year program at another university overseas or conducting work attachment in Brunei. Only 30 students from Level 1 participated in the pretest stage and were not included in the main study. There were no other inclusion and exclusion criteria. In Brunei, Japanese is studied by only few students, mostly females, although interest is steadily growing as stated above. The gender composition of the participants in the trial sample and main study sample is presented in Table 1 together with the respondents' age (mean and standard deviation).

Table 1. Gender and age characteristics of the participants

\begin{tabular}{llll}
\hline Study & Group & Mean & Standard Deviation \\
\hline \multirow{3}{*}{ Pilot study } & All $(\mathrm{N}=30)$ & 19.733 & 1.311 \\
& Females $(\mathrm{n}=16)$ & 19.437 & 0.727 \\
& Males $(\mathrm{n}=14)$ & 20.071 & 1.730 \\
\hline \multirow{3}{*}{ Main study } & All $(\mathrm{N}=141)$ & 21.346 & 1.960 \\
& Females $(\mathrm{n}=80)$ & 21.337 & 1.727 \\
& Males $(\mathrm{n}=61)$ & 21.361 & 2.243 \\
\hline
\end{tabular}

\subsection{Instruments}

The quantitative data for the pilot study were collected using two sets of questionnaires. The questions in the first set (Scale 1) were adapted from those used by Guo and Ookita (2001) while the items in the second set (Scale 2) were adapted from those used by Nuibe, Karino, and Ito (1995). The changes made to the items were minor and clarified mainly some English words to suit them for the Brunei sample. Studies by Guo and Ookita (2001), and Nuibe, Karino, and Ito (1995) had, in turn, based their questionnaires on Gardner's (2004) Attitudes/Motivation Test Battery (AMTB). The first set, Scale 1, had 41 items while the second set (Scale 2) had 39 items. All the items in Scale 1 and Scale 2 sought to identify the students' motivation for learning Japanese language. 
Participants responded to each item on both instruments using a 5-point Likert scale scored as Strongly Agree (5), Agree (4), Neutral (3), Disagree (2), and Strongly Disagree (1). Negative items on both scales were reverse scored to control measurement errors. The instrument of primary interest in the present study was Scale 1, which was used in the main study. Scale 2 was used in the pretest phase for purposes of validating Scale 1.

The Descriptive Statistics for both scales are presented in Table 2. As shown in this table, both scales were reliable for use with the Brunei sample in the present study. In addition, the two scales also had high criterion-related convergent/concurrent validity, which was obtained by correlating the participants' total scores on both instruments (Pearson $r(30)=0.776, p<.001$ ). Furthermore, since instruments were administered to all participants (in the pilot and main study) when they were in the lecture hall where they always received training in Japanese language (their usual university premises) we expect the data to have high ecological validity. Moreover, the data from both groups of participants were also expected to have reasonable social validity since the findings were to be used in improving effectively the teaching of Japanese language to Brunei students. To fulfill the fifth and last research objective, we also confidentially obtained used the participants' grades from the university records obtained on their Japanese course in the previous semester. Although the participants were at different levels of proficiency in Japanese language, the grading scheme was standardized and the grades conveyed the following common meaning: A (80-100\%); B (70-79\%); C (60-69\%); D (50-59\%); E (40-49\%); and $\mathrm{F}(0-39 \%)$. We used these grades to compare the motivation of students of different ability levels in Japanese language.

Table 2. Descriptive Statistics and reliability for data collection instruments

\begin{tabular}{lccc}
\cline { 2 - 3 } Statistic & Scale 1 & Scale 2 \\
\cline { 2 - 4 } Mean & 154.333 & 147.467 \\
SD & 11.627 & 13.691 \\
Reliability & 0.824 & 0.878 \\
SEm* & 2.122 & 2.499 \\
\hline
\end{tabular}

$*$ SEm $=$ Standard Error of measurement

\subsection{Data Analysis}

Quantitative data from four cross-sections of the main study sample (gender, age-groups, educational levels, and ability in Japanese language) were analyzed by both descriptive statistics (frequencies, percentages, mean and standard deviation) and inferential statistics (t-test for independent samples incorporating ANCOVA F, Person's correlation, and One-Way ANOVA). The rationale and justification for using these techniques is two-fold. First, the procedures were considered to be appropriate for addressing the research objectives. Second, the data were obtained from a population (all students studying the Japanese language) and there was no violation of any statistical assumption. In order to clarify the structure of factors embedded among the 41 items in Scale 1, a principal components exploratory factor analysis (EFA) with varimax rotation was conducted on SPSS Version 17. Only factors meeting the Kaiser criterion of eigenvalue $\geq 1$ and a minimum of 3 items were to be included in the rest of the study. With regard to items, only those loading \pm 0.400 and above to their respective factor were to be retained in the study. There were no other inclusion and exclusion criteria for factors and items. When an item cross-loaded on more than one component, the factor with the highest absolute loading was considered.

\subsection{Procedure}

Prior to collecting the data, permission to conduct the study was obtained from the University of Brunei Ethics Committee. The ethical conditions for being involved in the study were explained verbally and in writing to both groups of research participants in the trial sample and main study sample. The discussion of the participants' legal and ethical rights in research focused on issues such as voluntary participation, privacy, anonymity, confidentiality, protection from harm (physical and psychological), deception, debriefing, duty to care, and informed consent. All the participants in both groups voluntarily agreed to participate in the study and signed a consent form guaranteeing anonymity and confidentiality, among other rights. Based on this informed consent, they were then administered the data collection instruments.

With regard to English language problems, the meaning of difficult English words, sentences and phrases in items on the instruments were verbally explained to the participants. Some items were modified to suit the 
participants' level of English. Furthermore, students at the participants' university take most courses in English language and have participated in many research studies that required them to complete self-report scales or questionnaires in English. The researchers therefore considered it not necessary to translate the instruments into Bahasa Melayu (Brunei's mother tongue and official language). In this way, data collection conformed to the ethical requirements stipulated by the participants' university, the Government of Brunei, and the Helsinki Declaration on the use of human participants in research studies.

\section{Results of the Study}

The findings are presented below under separate subheadings but according to the objectives of the study.

\subsection{Types of Motivation Influencing Brunei Students in Studying Japanese Language}

Based on data generated by the research instrument from the Brunei sample, EFA with varimax rotation produced 5 factors with eigenvalues greater than 1 and items loading 0.400 and above. As a result of the stringent factor and item selection criteria, one factor with one single item was excluded from the study, as were items $6,10,14,15$ and 17 with absolute factor loadings less than 0.400 . The 5 factors that emerged and we extracted are presented in Table 3. Altogether they accounted for $43.935 \%$ of the total variance in explaining the five components. In the context of the present study, each of the 5 factors was regarded to be a subscale. After exhaustive item analyses and constant comparison of the items (Lincoln \& Guba, 1985; Patton, 1990), the 5 obtained factors or subscales were given the following names: Factor 1- Interest in Japanese pop culture and traditional culture orientation; Factor 2-Career use of Japanese language orientation; Factor 3-Self-satisfaction orientation; Factor 4. Understanding Japanese people and society orientation; and Factor 5-Interest in Japanese Language Orientation. These factors represent Brunei students' motivation for studying the Japanese language.

Table 3. Rotated factor components matrix

\begin{tabular}{|c|c|c|c|c|c|}
\hline Item & Factor 1 & Factor 2 & Factor 3 & Factor 4 & Factor 5 \\
\hline 8 & 0.724 & & & & \\
\hline 13 & 0.701 & & & & \\
\hline 12 & 0.698 & & & & \\
\hline 11 & 0.663 & & & & \\
\hline 30 & 0.581 & & & & \\
\hline 7 & 0.553 & & & & \\
\hline 9 & 0.528 & & & & \\
\hline 19 & & 0.755 & & & \\
\hline 34 & & 0.708 & & & \\
\hline 18 & & 0.676 & & & \\
\hline 16 & & 0.647 & & & \\
\hline 25 & & 0.513 & & & \\
\hline 39 & & 0.456 & & & \\
\hline 4 & & 0.431 & & & \\
\hline 31 & & & 0.652 & & \\
\hline 36 & & & 0.637 & & \\
\hline 37 & & & 0.571 & & \\
\hline 5 & & & 0.56 & & \\
\hline 27 & & & 0.544 & & \\
\hline 38 & & & 0.535 & & \\
\hline 26 & & & 0.476 & & \\
\hline 40 & & & 0.474 & & \\
\hline 28 & & & 0.459 & & \\
\hline
\end{tabular}




\begin{tabular}{|c|c|c|c|c|c|}
\hline 32 & & & 0.446 & & \\
\hline 24 & & & & 0.632 & \\
\hline 21 & & & & 0.59 & \\
\hline 20 & & & & 0.586 & \\
\hline 35 & & & & 0.578 & \\
\hline 22 & & & & 0.527 & \\
\hline 23 & & & & 0.483 & \\
\hline 2 & & & & & 0.731 \\
\hline 3 & & & & & 0.622 \\
\hline 1 & & & & & 0.588 \\
\hline 33 & & & & & 0.412 \\
\hline Eigenvalue & 8.094 & 3.662 & 2.256 & 1.985 & 1.578 \\
\hline$\%$ Variance explained & 20.234 & 9.155 & 5.64 & 4.961 & 3.945 \\
\hline Total variance & & & $43.94 \%$ & & \\
\hline
\end{tabular}

\subsection{Differences in Motivation by Gender}

Only two significant differences were obtained in Table 4. Males scored significantly higher than females on Factor 1 but the two genders reversed their positions on Factor 3. This finding implies that male students' motivation to learn Japanese language tends to be more driven by Japanese culture compared to female students' motivation. On the other hand, the driving force for female students to learn Japanese language derives from self-esteem or self-respect achieved from learning Japanese language.

Table 4. Differences in motivation by gender $(\mathrm{N}=141)$

\begin{tabular}{|c|c|c|c|c|c|c|c|c|}
\hline \multirow{2}{*}{$\begin{array}{l}\text { Factors }^{\mathrm{a}} \\
\text { (Scales) }\end{array}$} & \multicolumn{2}{|c|}{ Male $(n=61)$} & \multicolumn{2}{|c|}{ Female $(n=80)$} & \multirow{2}{*}{ ANCOVA F } & \multirow{2}{*}{$\frac{T}{(d f=139)}$} & \multirow{2}{*}{$\frac{P}{\text { (2-tailed) }}$} & \multirow{2}{*}{$\mathrm{ES}^{\dagger}$} \\
\hline & Mean & SD & Mean & SD & & & & \\
\hline Factor 1 & 28.982 & 4.022 & 26.412 & 4.796 & 0.685 & 2.193 & $0.030^{*}$ & 0.183 \\
\hline Factor 2 & 24.789 & 4.235 & 23.812 & 3.625 & 1.441 & 1.47 & 0.144 & 0.124 \\
\hline Factor 3 & 29.639 & 5.882 & 31.537 & 4.802 & 2.829 & -2.109 & $0.037^{*}$ & 0.176 \\
\hline Factor 4 & 27.934 & 2.151 & 27.425 & 2.32 & 0.619 & 1.332 & 0.185 & 0.112 \\
\hline Factor 5 & 18.885 & 1.379 & 18.375 & 1.656 & $6.605^{*}$ & 1.945 & 0.054 & 0.163 \\
\hline
\end{tabular}

\section{$\mathrm{ES} \dagger=$ Effect Size}

$* \mathrm{p}<.05$ (2-tailed)

${ }^{a}$ Factor / Scale names:

Factor 1-Interest in Japanese pop culture and traditional culture orientation

Factor 2-Career use of Japanese language orientation

Factor 3-Self-satisfaction orientation

Factor 4-Understanding Japanese people and society orientation

Factor 5-Interest in Japanese Language Orientation

\subsection{Differences in Motivation by Age-Groups}

No significant difference was obtained between the groups (see Table 5). However, students in the older age-group (24-27) slightly scored higher than their counterparts in the other two age-groups. 
Table 5. Differences in motivation by age-groups $(\mathrm{N}=140)^{\mathrm{a}}$

\begin{tabular}{|c|c|c|c|c|c|c|}
\hline \multirow[t]{2}{*}{ Factors $^{\mathrm{b}}$} & Aged $18-20(n=53)$ & Aged $21-23(n=71)$ & Aged $24-27(n=16)$ & \multirow[t]{2}{*}{$\mathrm{F}(d f=2 ; 137)$} & \multirow[t]{2}{*}{ P (2-tailed) } & \multirow[t]{2}{*}{ Eta } \\
\hline & Mean (SD) & Mean (SD) & Mean (SD) & & & \\
\hline \multirow{2}{*}{ Factor 1} & 26.660 & 27.225 & 28.250 & 0.778 & 0.461 & 0.106 \\
\hline & $(4.518)$ & $(4.736)$ & $(3.82)$ & & & \\
\hline \multirow{2}{*}{ Factor 2} & 24.226 & 24.098 & 25.000 & 0.342 & 0.711 & 0.071 \\
\hline & $(4.074)$ & $(4.123)$ & $(2.280)$ & & & \\
\hline \multirow{2}{*}{ Factor 3} & 30.905 & 30.295 & 31.687 & 0.507 & 0.603 & 0.086 \\
\hline & $(5.478)$ & $(5.645)$ & (3.497) & & & \\
\hline \multirow{2}{*}{ Factor 4} & 27.037 & 27.985 & 28.125 & 3.168 & $0.045^{*}$ & 0.210 \\
\hline & $(2.579)$ & $(1.974)$ & $(2.028)$ & & & \\
\hline \multirow{2}{*}{ Factor 5} & 18.245 & 18.788 & 18.875 & 2.163 & 0.119 & 0.175 \\
\hline & $(1.817)$ & $(1.275)$ & $(1.707)$ & & & \\
\hline
\end{tabular}

$* \mathrm{p}<.05$ (2-tailed)

${ }^{\text {a }}$ One outlier case was deleted for being over-aged

${ }^{\mathrm{b}}$ See Table 4 for factor / scale names

\subsection{Differences in Motivation by Japanese Language Levels}

Table 6 shows that there were no significant differences in motivation by Japanese language levels. This indicates that when levels of Japanese proficiency get higher, students' motivational factors in learning Japanese language do not change, and they maintain them from elementary to advanced levels. In addition, it can also be observed from Table 6 that students in all the 5 levels scored highest on Factor 3 (Self-satisfaction orientation). At UBD where learners do not have much access to the target language and culture (Japanese), it seems that the main motivation sustaining them is self-satisfaction.

Table 6. Differences in motivation by Japanese language levels ( $\mathrm{N}=141)$

\begin{tabular}{|c|c|c|c|c|c|c|c|c|}
\hline Factors $^{\mathrm{a}}$ & $\begin{array}{c}\text { Level } 1 \\
(\mathrm{n}=61) \\
\text { Mean (SD) }\end{array}$ & $\begin{array}{c}\text { Level } 2 \\
(\mathrm{n}=33) \\
\text { Mean (SD) }\end{array}$ & $\begin{array}{c}\text { Level } 3 \\
(\mathrm{n}=15) \\
\text { Mean (SD) }\end{array}$ & $\begin{array}{c}\text { Level } 4 \\
(\mathrm{n}=23) \\
\text { Mean (SD) }\end{array}$ & $\begin{array}{c}\text { Level } 6 \\
(\mathrm{n}=9) \\
\text { Mean (SD) }\end{array}$ & $\begin{array}{c}\mathrm{F} \\
(d f=4 ; 136)\end{array}$ & $\begin{array}{c}\mathrm{P} \\
\text { (2-tailed) }\end{array}$ & Eta \\
\hline Factor 1 & $\begin{array}{l}26.738 \\
(4.169)\end{array}$ & $\begin{array}{c}26.09 \\
(5.375)\end{array}$ & $\begin{array}{l}28.333 \\
(5.122)\end{array}$ & $\begin{array}{l}28.956 \\
(3.522)\end{array}$ & $\begin{array}{l}28.111 \\
(3.789)\end{array}$ & 2.018 & 0.095 & 0.237 \\
\hline Factor 2 & $\begin{array}{l}23.868 \\
(3.801)\end{array}$ & $\begin{array}{l}23.454 \\
(4.402)\end{array}$ & $\begin{array}{l}25.733 \\
(4.542)\end{array}$ & $\begin{array}{l}25.565 \\
(2.904)\end{array}$ & $\begin{array}{l}23.666 \\
(3.162)\end{array}$ & 1.758 & 0.141 & 0.222 \\
\hline Factor 3 & $\begin{array}{l}31.786 \\
(4.872)\end{array}$ & $\begin{array}{l}29.727 \\
(5.398)\end{array}$ & $\begin{array}{l}30.266 \\
(6.134)\end{array}$ & $\begin{array}{l}30.521 \\
(4.066)\end{array}$ & $\begin{array}{l}28.333 \\
(8.789)\end{array}$ & 1.383 & 0.243 & 0.198 \\
\hline Factor 4 & $\begin{array}{l}27.803 \\
(2.112)\end{array}$ & $\begin{array}{l}27.484 \\
(2.399)\end{array}$ & $\begin{array}{l}27.933 \\
(1.830)\end{array}$ & $\begin{array}{l}27.739 \\
(2.614)\end{array}$ & $\begin{array}{l}26.444 \\
(2.403)\end{array}$ & 0.821 & 0.514 & 0.154 \\
\hline Factor 5 & $\begin{array}{l}18.311 \\
(1.717)\end{array}$ & $\begin{array}{l}18.636 \\
(1.410)\end{array}$ & $\begin{array}{l}18.800 \\
(1.473)\end{array}$ & $\begin{array}{l}19.260 \\
(1.214)\end{array}$ & $\begin{array}{l}18.333 \\
(1.581)\end{array}$ & 1.724 & 0.148 & 0.220 \\
\hline
\end{tabular}

${ }^{\mathrm{a}}$ See Table 4 for factor/scale names

\subsection{Differences in Motivation by Grades obtained on Japanese Course}

Evidence in Table 7 revealed only one significant difference on Factor 5 (Interest in Japanese Language Orientation) where more-able students scored highest. Therefore, higher achievers tend to have more integrative 
motivation compared to low achievers. In UBD where Japanese language is not a major, but rather a minor subject, eagerness to study Japanese language and academic achievement have been observed to have a positive relationship but this claim is not measured in the present study.

Table 7. Differences in motivation by grades obtained on a Japanese course $(\mathrm{N}=141)$

\begin{tabular}{lccccccc}
\hline & Grade D & Grade C & Grade B & Grade A & $\mathrm{F}$ & $\mathrm{P}$ & \\
\cline { 2 - 6 } Factors $^{\mathrm{a}}$ & $(\mathrm{n}=15)$ & $(\mathrm{n}=28)$ & $(\mathrm{n}=74)$ & $(\mathrm{n}=24)$ & $(d f=3 ; 137)$ & $(2$-tailed) & Eta \\
& Mean (SD) & Mean (SD) & Mean (SD) & Mean (SD) & & & \\
\hline \multirow{2}{*}{ Factor 1 } & 26.533 & 26.821 & 27.148 & 27.833 & 0.317 & 0.813 & 0.083 \\
& $(4.501)$ & $(4.009)$ & $(4.767)$ & $(4.603)$ & & & \\
Factor 2 & 24.933 & 24.714 & 23.973 & 24.041 & 0.423 & 0.737 & 0.096 \\
& $(3.807)$ & $(3.619)$ & $(4.141)$ & $(3.723)$ & & & \\
Factor 3 & 31.000 & 29.857 & 31.013 & 30.625 & 0.327 & 0.806 & 0.084 \\
& $(3.565)$ & $(5.226)$ & $(5.765)$ & $(5.322)$ & & & \\
Factor 4 & 27.933 & 27.857 & 27.351 & 28.125 & 0.943 & 0.422 & 0.142 \\
& $(2.344)$ & $(1.976)$ & $(2.313)$ & $(2.327)$ & & & \\
Factor 5 & 17.533 & 18.571 & 18.675 & 19.041 & 3.189 & $0.026^{*}$ & 0.255 \\
& $(1.884)$ & $(1.168)$ & $(1.588)$ & $(1.428)$ & & & \\
\hline
\end{tabular}

${ }^{\text {a }}$ See Table 4 for factor/scale names

$* \mathrm{P}<.05$ (2-tailed)

\section{Discussion}

Nuibe, Kano, and Ito (1995) proposed the categorization that Instrumental Motivation, Integrative Motivation, and Provocative Motivation can be classified under Extrinsic Motivation, while "interest and curiosity", "identification with the model", and "Interaction with peers" can be categorized under Intrinsic Motivation. "Interest and curiosity" refers to interest in Japanese language and Japanese culture and a desire to know Japanese people. "Identification with the model" means for example, the motive to admire the teacher who speaks Japanese well and wish to be able to speak Japanese fluently like the teacher. "Interaction with peers" refers to the desire to communicate with Japanese people by using Japanese.

In Nuibe, Kano, and Ito (1995)'s research, six motivational factors were extracted. They were named as "understanding Japan", "interest in Japanese language study", "interest in international issues", "Integrative orientation", "provocative orientation" and "instrumental orientation". "Understanding Japan" was categorized into "curiosity" and "interest in Japanese language study" was categorized into "Interest", and "interest in international issues" was categorized into "Interaction with peers" which are under intrinsic motivation, while "Integrative orientation", "provocative orientation" and "instrumental orientation" were categorized into extrinsic motivation. However, they could not find an appropriate main factor for "Identification with the model". In the present study, we also obtained six motivational factors but the sixth factor was deleted because it had only one item that loaded high on it to the criterion level. This process then left us with only five factors reported in Table 4.

In terms of names given by Nuibe, Kano, and Ito (1995) and us in the present study to the identified motivational factors, there are both similarities and differences. For example, the factor named as "understanding Japan" by Nuibe, Kano, and Ito (1995) is equivalent to Factor 4 - Understanding Japanese people and society orientation, in the present study. In the same way, the factor referred to as "interest in Japanese language study" by Nuibe, Kano, and Ito (1995) somewhat resembles Factor 5 - Interest in Japanese Language Orientation, in our study. The rest of the factors in the two studies have non-comparable different names. This is understandable and defendable since the two studies used completely different samples. However, as Narita (1998) points out, there are some motivational elements, which are difficult to classify as extrinsic motivation or intrinsic motivation, such as "I want to communicate with Japanese friends in Japanese language". This element could be integrative motivation if using Japanese language is the learners' purpose. However, if making Japanese friends is the learners' purpose 
and learning Japanese is the means to make Japanese friends, it could be categorized as extrinsic motivation. Therefore, drawing a strict distinguishing line between intrinsic and extrinsic motivation could be regarded as being problematic and even counterproductive. Due to this problem, the present study focused more on three categorizations of motivation, namely: integrative; instrumental; and provocative motivation.

As pointed out in the literature review (above in Section 1.2), there are other forms of motivation that indirectly facilitate Brunei students' success in learning foreign languages. For instance the motivation, which comes through possessing self-efficacy is quite important (see Tait \& Mundia, 2014). The use of appropriate and effective learning styles and study strategies would be other sources of internal and external motivation in Brunei students (Shahrill, Mahalle et al., 2013). There is also evidence from previous research that the ability of a learner to solve and cope effectively with academic and personal problems could impact motivation positively (Mundia, 2010c; Shahrill \& Mundia, 2014a; Wahid \& Shahrill, 2014).

\section{Conclusion and Recommendations}

The present research investigated Japanese language learners' motivation among Brunei students at UBD as well as differences in motivation according to gender, age-groups, proficiency levels, and academic achievement. Five motivational factors were obtained: (1) Interest in Japanese pop culture and traditional culture; (2) Interest in Japanese language orientation; (3) Understanding Japanese people and society orientation; (4) Career use of Japanese language orientation; and (5) Self-satisfaction orientation. Participants differed in motivation by gender and age-group. Males were more driven to learn Japanese language by "interest in Japanese pop culture and traditional culture" compared to females whose desire to learn Japanese language was mostly inspired by self-esteem or self-satisfaction in Japanese language achievement. Evidence also showed that participants in the oldest age-group (24-27) scored significantly higher than peers in other age-groups on the factor labelled as "Understanding Japanese People and Society Orientation".

Based on the findings from the present study as well as motivational strategies proposed by Dörnyei (2001), the following list of (illustrative but not exhaustive) recommendations is made for Japanese language instructors at the University of Brunei Darussalam:

- Instructors should create learning activities which encourage interaction with native speakers of Japanese language, where and whenever possible. Higher level learners can undertake an interview program while lower level learners may take part in dialogues and role plays.

- Instructors should ensure greater use of authentic materials. At lower levels these may need adjustment to ensure that they are pedagogically appropriate.

- Instructors should ensure greater use of multimedia and online technologies to facilitate interactions with target language speakers.

- Instructors should encourage presentations by students and other persons who have experienced staying in Japan.

- Instructors should create and maintain a pleasant, accepting and supportive class learning environment and strengthen group cohesiveness.

- Instructors should use a variety of learning materials and activity tasks for teaching and learning to be stimulating, exciting and enjoyable experiences.

- Instructors should foster students' extrinsic motivation by promoting team work, collaboration, and cooperation among learners.

- Instructors should encourage the students' positive self-evaluation and self-direction by giving appropriate feedback.

- Future research by instructors and other educators should address, among other issues, the relationship between teaching strategies, motivation, and academic achievement in the learning of Japanese language in Brunei tertiary institutions.

\section{Limitation of the Study}

The present study was informed by three main limitations. First, being a survey, the research could not establish any cause-and-effect relationships among the variables investigated as the study was not experimental and we did not perform any regression analyses. Second, we only used exploratory factor analysis (EFA) to generate the 5 factors employed in the study. These were supposed to be confirmed using confirmatory factor analysis (CFA) but we did not do this due to lack of appropriate software such as AMOS, LISREL, and SAS. Third, for the sake 
of brevity, we did not include findings from the qualitative component to complement or supplement the results of the quantitative survey. Despite these shortcomings, the study has practical significance and might be of value to teachers of the Japanese language in foreign contexts (outside Japan).

\section{References}

Ang, L. H., \& Shahrill, M. (2014). Identifying students' specific misconceptions in learning probability. International Journal of Probability and Statistics, 3(2), 23-29. http://dx.doi.org/10.5923/j.ijps.20140302.01

Bradshaw, L., \& Mundia, L. (2006). Attitudes to and concerns about inclusive education: Bruneian inservice and preservice teachers. International Journal of Special Education, 21(1), 35-41.

Daud, D. S. M. P., \& Shahrill, M. (2014). Examining the effectiveness of peer mentoring in the learning of differentiation. Paper presented at the $6^{\text {th }}$ International Conference on Education and New Learning Technologies (EDULEARN14), Barcelona, Spain, 7-9 July 2014.

Dörnyei, Z. (2001). New themes and approaches in second language motivation research. Annual Review of Applied Linguistics, 21, 43-59. http://dx.doi.org/10.1017/S0267190501000034

Flanagan, C. (2000). AS/A-Level Psychology: Essential word dictionary. Oxfordshire: Philip Allan Updates.

Gardner, R. C. (1985). Social Psychology and Second Language Learning: The role of Attitudes and Motivation. London: Edward Amold.

Gardner, R. C. (2004). Attitude/Motivation Test Battery. London, ON: University of Western Ontario, Canada. Retrieved from http://publish.uwo.ca/ gardner/docs/englishamtb.pdf

Gardner, R. C., \& Lambert, W. E. (1972). Attitudes and motivation in second language learning. Rowley, MA: Newbury House.

Gardner, R. C., Lalonde, R. N., Moorcroft, R., \& Evers, F. T. (1987). Second language attrition: The role of motivation and use. Research Bulletin, 638. Ontario: University of Western Ontario. http://dx.doi.org/10.1016/S0140-6736(87)90384-9

Go, B. T., \& Shahrill, M. (2014). Investigating students' learning of function notation. Proceedings of the 2nd International Conference on Social Sciences Research (pp. 399-408). Kota Kinabalu, Sabah, Malaysia: ICSSR 2014.

Guo, J., \& Ookita, Y. (2001). Singaporu kajin daigakusei no Nihongogakushuu no doukizuke nitsuite. Nihongokyouiku, 110, 130-139.

Guo, J., \& Quan, J. (2006). Motivation of Chinese university students towards learning Japanese. Journal of the International Support Exchange Centre, 2, 118-128.

Hamid, M. H. S., Shahrill, M., Matzin, R., Mahalle, S., \& Mundia, L. (2013). Barriers to mathematics achievement in Brunei secondary school students: Insights into the roles of mathematics anxiety, self-esteem, proactive coping, and test stress. International Education Studies, 6(11), 1-14. http://dx.doi.org/10.5539/ies.v6n11p1

Haq, F. S., \& Mundia, L. (2012). Comparison of Brunei pre-service student teachers' attitudes to inclusive education and specific disabilities: Implications for teacher education. Journal of Educational Research, 105(5), 366-374. http://dx.doi.org/10.1080/00220671.2011.627399

Jaidin, J. H. (2009). Conceptions of learning held by upper primary children in government schools in Brunei Darussalam (Unpublished doctoral dissertation). Queensland University of Technology, Brisbane, Australia.

Jawawi, R. (2009). Conceptions of economics pre-services teacher's use of subject knowledge in teaching, economics and commerce at secondary schools in Brunei Darussalam (Unpublished doctoral dissertation). University of London, London, United Kingdom.

Jawawi, R. (2010). Reflective practice in teaching economics and commerce: A case study of pre-service teachers in Brunei Darussalam. Saarbrücken, Germany: VDM Verlag Dr. Müller.

Krahen, S. D. (1981). Second Language Acquisition and Second Language Learning. Oxford, UK: Pergamon.

Lincoln, Y. S., \& Guba, E. G. (1985). Naturalistic inquiry. Newbury Park, CA: Sage Publications.

Mahadi, M. A. H., \& Shahrill, M. (June, 2014). In pursuit of teachers' views on the use of textbooks in their classroom practice. International Journal of Education, 6(2), 149-158. 
http://dx.doi.org/10.5296/ije.v6i2.5637

Mahalle, S., Matzin, R., Hamid, M. H. S., Shahrill, M., \& Mundia, L. (2014). Brunei Student Teachers' Selected Personal Attributes, Attitudes to Women and Interpersonal Trust: Brief Psychological Report. Asian Social Science, 10(1), 151-157. http://dx.doi.org/10.5539/ass.v10n1p151

Matzin, R., Shahrill, M., Mahalle, S., Hamid, M. H. S., \& Mundia, L. (2013). A Comparison of Learning Styles and Study Strategies Scores of Brunei Secondary School Students by Test Anxiety, Success Attributions, and Failure Attributions: Implications for Teaching At-risk and Vulnerable Students. Review of European Studies, 5(5), 119-127. http://dx.doi.org/10.5539/res.v5n5p119

Moriya, T. (2002). Dainigengokyooiku niokeru dookizuke no kenkyuudookoo-Dainigengo toshite no Nihongo no dookizuke kenkyuu o shooten toshite-. Gengobunka to Nihongokyooiku, May, 315-329.

Mundia, L. (1998). The status of vocational and technical education in Papua New Guinea: A survey of attitudes. Science, Technology and Development, 16(2), 104-111.

Mundia, L. (2009). Implementation of inclusive education in Brunei Darussalam: Review of possible implications on school counsellors. Electronic Journal for Inclusive Education, 2(4). Spring/Summer Issue. Retrieved from http://www.cehs.wright.edu/ prenick/Spring_Summer09_Edition/spr_sum09.html

Mundia, L. (2010a). Implementation of SPN21 curriculum in Brunei Darussalam: A review of selected implications on school assessment reforms. International Education Studies, 3(2), 119-129. http://dx.doi.org/10.5539/ies.v3n2p119

Mundia, L. (2010b). Problems in learning mathematics: Comparison of Brunei junior high school students in classes with and without repeaters. Journal of Mathematics Research, 2(3), 150-160. http://dx.doi.org/10.5539/jmr.v2n3p150

Mundia, L. (2010c). Brunei trainee teachers' coping strategies for stressful situations. International Journal of Psychological Studies, 2(1), 79-88. http://dx.doi.org/10.5539/ijps.v2n1p79

Mundia, L. (2011). Social desirability, non-response bias and reliability in a long self-report measure: Illustrations from the MMPI-2 administered to Brunei student teachers. Educational Psychology, 31(2), 207-224. http://dx.doi.org/10.1080/01443410.2010.545049

Mundia, L. (2012a). Policy changes in Brunei teacher education: Implications for the selection of trainee teachers. The Education Forum, 76(3), 326-342. http://dx.doi.org/10.1080/00131725.2012.682489

Mundia, L. (2012b). The Assessment of Mathematics Learning Difficulties in a Primary Grade 4 Child with High Support Needs: Mixed Methods Approach. International Electronic Journal of Elementary Education, 4(2), 347-366. http://dx.doi.org/10.1080/00131725.2012.682489

Mundia, L. (2012c). Assessment of GenNEXT learning outcomes at the University of Brunei Darussalam: A qualitative review of selected opportunities, benefits and challenges in human resource development. Journal of International Education and Leadership, 2(3), Fall 2012.

Mundia, L., \& Bakar, H. A. Z. B. A. (2010). The suitability of the EPQ-R short scale for counseling Brunei student teachers when administered in English and Malay languages. Compare, 40(5), 641-658. http://dx.doi.org/10.1080/03057920903478654

Narita, T. (1998). Nihongo gakushuu dooki to seiseki tono kankei-Tai no daigakusei no baai-. Sekai no Nihongokyouiku, 8, 1-11.

Nor, H. N. H. M., \& Shahrill, M. (2014). Incorporating the use of poster and oral presentations as an alternative assessment in the teaching of secondary mathematics. Proceedings of the $2^{\text {nd }}$ International Conference on Social Sciences Research (pp. 369-378). Kota Kinabalu, Sabah, Malaysia: ICSSR 2014.

Nuibe, Y., Kano, F., \& Ito, K. (1995) Daigakusei no Nihongo gashuu douki ni kansuru kokusai chousa-New Zealand no baai-. Nihongokyouiku, 86, 162-172.

Onishi, Y. (2011). A survey of motivations among Ukrainian university students of Japanese: The relationship between learners' motivations and their expectations of achievement. The Journal of International Media, Communication, and Tourism Studies, 12, 21-40.

Patton, M. Q. (1990). Qualitative evaluation and research methods. Newbury Park, CA: Sage Publications.

Pungut, M. H. A., \& Shahrill, M. (2014). Students' English language abilities in solving mathematics word problems. Mathematics Education Trends and Research, 1-11. http://dx.doi.org/10.5899/2014/metr-00048 
Salam, N. H. A., \& Shahrill, M. (2014). Examining classroom interactions in secondary mathematics classrooms in Brunei Darussalam. Asian Social Science, 10(11), 92-103. http://dx.doi.org/10.5539/ass.v10n11p92

Sarwadi, H. R. H., \& Shahrill, M. (2014). Understanding students' mathematical errors and misconceptions: The case of year 11 repeating students. Mathematics Education Trends and Research, 1-10. http://dx.doi.org/10.5899/2014/metr-00051

Seo, M. (2011). The motivational shift of Japanese life-long learners in Hong Kong: Investigating motivation through the Modified-Grounded Theory Approach (M-GTA). Nihongakkan, 14, 16-39.

Shahrill, M. (2009). From the general to the particular: Connecting international classroom research to four classrooms in Brunei Darussalam (Unpublished doctoral dissertation). University of Melbourne, Melbourne, Australia.

Shahrill, M. (2013a). Review of teacher questioning in mathematics classrooms. International Journal of Humanities and Social Science, 3(17), 224-231.

Shahrill, M. (2013b). Comparing teacher questioning in American and Australian mathematics classrooms. Journal of Applied Research in Education, 17, 26-40.

Shahrill, M., \& Clarke, D. J. (2014). Brunei Teachers' Perspectives on Questioning: Investigating the Opportunities to 'Talk' in Mathematics Lessons. International Education Studies, 7(7), 1-18. http://dx.doi.org/10.5539/ies.v7n7p1

Shahrill, M., \& Mundia, L. (2014a). Coping Behavior of International Late Adolescent Students in Selected Australian Educational Institutions. Global Journal of Health Science, 6(1), 76-91. http://dx.doi.org/10.5539/gjhs.v6n1p76

Shahrill, M., \& Mundia, L. (2014b). The use of low-order and higher-order questions in mathematics teaching: Video analyses case study. Journal of Studies in Education, 4(2), 15-34. http://dx.doi.org/10.5296/jse.v4i2.5318

Shahrill, M., Abdullah, N. A., \& Yusof, J. (2014). Research Report: Teachers and Teaching of Mathematics in Primary Schools in Brunei Darussalam. Ministry of Education, Brunei Darussalam.

Shahrill, M., Abdullah, N. A., Yusof, J., \& Suhaili, A. S. (2014). Informing the practice of teaching mathematics in upper primary classes. In I. Sahin, S. A. Kiray, \& S. Alan (Eds.), Proceedings of the International Conference on Education in Mathematics, Science \& Technology (pp. 168-172). Konya, Turkey: Necmettin Erbakan University.

Shahrill, M., Lim, S. B., Poh, S. H., \& Riah, H. (2013). Parenting styles of Bruneian youths' parents. Proceedings of the International Conference on Youth 2013 (pp. 111-120). Serdang, Selangor: Institute for Social Science Studies, University Putra Malaysia.

Shahrill, M., Mahalle, S., Matzin, R., Hamid, M. H. S., \& Mundia, L. (2013). A comparison of learning styles and study strategies used by low and high math achieving Brunei secondary school students: Implications for teaching. International Education Studies, 6(10), 39-46. http://dx.doi.org/10.5539/ies.v6n10p39

Shumann, J. K. (1988). Research on the acculturation model for second language acquisition. In T. J. Quinn, \& T. F. Mcnamara (Eds.), Issues in Second Language Learning: General and Particular (pp. 83-94). Victoria: Deakin University Press.

Silva, I. M., \& Weinberg, R. S. (1984). Psychological foundations of sports. Champaign, IL: Human Kinetics Publishers, Inc.

Tait, K., \& Mundia, L (2014). A Comparison of Brunei and Hong Kong-SAR Student Teachers' Self-efficacy in Implementing Inclusive Education Practices: Implications for Teacher Education. Asian Social Science, 10(1), 51-60. http://dx.doi.org/10.5539/ass.v10n1p51

Tait, K., \& Mundia, L. (2012a). The impact of a child with autism on the Bruneian family system. International Journal of Special Education, 27(3), 199-212.

Tait, K., \& Mundia, L. (2012b). Preparing teachers to meet the challenges of inclusive education in Negara Brunei Darussalam. In C. I. Forlin (Ed.), Future directions for inclusive teacher education: An international perspective (pp. 60-69).

Tait, K., Mundia, L., \& Fung, F. (2014). Raising Young Children with Autism Spectrum Disorders in Hong Kong: The Impact of Cultural Values and Stigma on Chinese Parents' Coping strategies. International Journal of 
Advances in Social Science and Humanities, 2(1), 7-15. Retrieved from http://www.ijassh.com

Wahid, N. A., \& Shahrill, M. (2014). Pre-university students' engagement towards the learning of mathematics. Proceedings of the $2^{\text {nd }}$ International Conference on Social Sciences Research (pp. 379-388). Kota Kinabalu, Sabah, Malaysia: ICSSR 2014.

Yatab, R. S., \& Shahrill, M. (2014a). Examining the effectiveness of common assessment tasks in lower secondary science. Paper presented at the $14^{\text {th }}$ Annual Conference ASIA Pacific Science \& Technology Centre (ASPAC 2014), Bandar Seri Begawan, Brunei Darussalam, 5-8 May, 2014.

Yatab, R. S., \& Shahrill, M. (2014b). The differing views in using the common assessment tasks in secondary school science. International Journal of Science and Research, 3(7).

\section{Copyrights}

Copyright for this article is retained by the author(s), with first publication rights granted to the journal.

This is an open-access article distributed under the terms and conditions of the Creative Commons Attribution license (http://creativecommons.org/licenses/by/3.0/). 